\title{
Stage 0 Transitional Cell Carcinoma
}

National Cancer Institute

\section{Source}

National Cancer Institute. Stage O Transitional Cell Carcinoma. NCI Thesaurus. Code C4116.

A lesion in which the surface epithelium of the bladder or the renal pelvis and ureter contains transitional cells which display malignant cytologic characteristics. There is no evidence of stromal invasion. 